\title{
IM LEPIEJ, TYM GORZEJ ALBO WIDMO KRYZYSU MIEJSKICH RUCHÓW SPOŁECZNYCH?
}

Miejskie ruchy społeczne (MRS), aktywne w polu niezinstytucjonalizowanej polskiej polityki już od kilku lat, sa coraz wyraźniej obecne w centrum debaty politycznej. Część z nich przesuwa się też coraz wyraźniej $\mathrm{w}$ stronę zinstytucjonalizowanej polityki. Zakończone $\mathrm{w}$ listopadzie 2014 r. wybory samorządowe, w których wystartowała część środowisk MRS, wskazały na ich rosnące ambicje polityczne. „Wejście w system”, jakie nastapiło w kilku przypadkach, może być punktem przełomowym dla logiki rozwojowej MRS, przynajmniej dla części środowisk.

Przyglądam się rozwojowi oraz wewnętrznemu zróżnicowaniu MRS już od kilku lat, w prezentowanym artykule postaram się więc syntetycznie wskazać na kilka konsekwencji tych procesów, zarówno dla socjologii ruchów społecznych (kłopoty z teoria MRS, problem „współwytwarzania wiedzy", relatywizujący klasyczne podejście neopozytywistyczne), jak i dla samych ruchów (instytucjonalizacja i groźba „oligarchizacji”). Co istotne, analizując wskazane problemy, odwołuję się przede wszystkim do kontekstu potransformacyjnego ${ }^{1}$. Milcząco zakładana przeze mnie ramą analityczna jest bowiem „liberalna sfera publiczna” i jej demokratyczne prerogatywy.

\section{MIEJSKIE RUCHY SPOŁECZNE W POTRANSFORMACYJNEJ POLSCE}

Jeszcze bez mała dekadę temu badacze ruchów społecznych i społecznego aktywizmu w potransformacyjnej Polsce wieścili „społeczny bezruch”2. Obecnie mamy z kolei do czynienia $\mathrm{z}$ bezprecedensową erupcją zaangażowania.

${ }^{1}$ Nie odnoszę się zatem szerzej do tradycji badawczej, jaką ukonstytuował fenomen Solidarności w ramach - jak to określał Andrzej Maciej Kaniowski - „fasadowej sfery publicznej” PRL, mimo kilku analogii, które moglibyśmy wywieść między MRS a Solidarnością: równie silny był tam motyw inteligenckiego/akademickiego zaangażowania oraz kontekst współwytwarzania wiedzy; por. Por. A. M. Kaniowski, Polska sfera nie-publiczna, „Krytyka Polityczna” 2003, nr 3, s. 90-96; A. Touraine, Solidarność. Analiza ruchu społecznego 1980-1981, Gdańsk 2010.

${ }^{2}$ M. Nowak, M. Nowosielski (red.), Czy społeczny bezruch? O społeczeństwie obywatelskim i aktywności we wspótczesnej Polsce, Poznań 2006. 
Wpisać możemy ją częściowo w „boom miejski”, którego forpoczta - najpewniej, przynajmniej w formacyjnej fazie swojego istnienia, w nieintencjonalny sposób - stały się właśnie MRS.

Przestrzeń miejskiego aktywizmu jest dziś bardzo złożona, jednym zaś z jej planów, oprócz prób redefinicji czy też rekonstrukcji lokalnego (przede wszystkim) ładu demokratycznego, jest - jeśli ufać określonym tropom interpretacyjnym, lokującym aktualny fenomen miejskiego aktywizmu w perspektywie długiego trwania-redefinicja to żs a mości do tej pory postagrarnego, przede wszystkim „nie-miejskiego” społeczeństwa ${ }^{3}$ i najszerzej bodaj rozpowszechnionej w nim postchłopskiej tożsamości ${ }^{4}$. Miejscy aktywiści robia to w rozmaity sposób, bardzo odmiennie definiując też „problemy miejskie”. Wydaje się, że to właśnie odmienne postrzeganie „kwestii miejskiej” oraz rozmaite interpretowanie tego, czym i czyje jest „prawo do miasta” (the right to the city, RTTC), stanowią kluczowe, ale nie jedyne (i zapewne niewystarczajace) kryteria identyfikacji samych MRS oraz wewnętrznych zróżnicowań w ich obrębie.

W tym procesie (re)konstrukcji miejskiej tożsamości, w walkach o „dobrze urządzone miasto" uczestniczą bardzo różni aktorzy: sami obywatele oraz aktywiści, ale też władze samorząowe ${ }^{5}$, artyści i instytucje kultury ${ }^{6}$. Moda na miejskość staje się też elementem kapitalizmu kulturowego. Postacie takiego uczestnictwa też sa zróżnicowane: od polityki protestu (z której wyrasta część miejskich środowisk aktywistycznych), przez ograniczające się do określonych przestrzeni strategie „naprawcze” i różnorodne strategie partycypacyjne ${ }^{7}$, aż po rozmaite sposoby zagnieżdżania się w systemie.

$\mathrm{W}$ artykule dokonam oczywiście celowej redukcji - interesować mnie będa przede wszystkim MRS, w konieczny sposób odnosić się będę musiał jednak do systemu zinstytucjonalizowanej polityki oraz niejednoznacznych interakcji pomiędzy ruchem społecznym a polityka. Z jednej strony dochodzi bowiem do przechwytywania określonych postulatów MRS przez system polityczny, z drugiej - do próby otwartego i intencjonalnego wejścia przez MRS w ten system, przede wszystkim na poziomie lokalnym.

Ruchy społeczne o miejskim charakterze, bardziej precyzyjnie zaś - te spośród nich, które używają kategorii MRS autoreferencyjnie, pojawiły się na scenie niezinstytucjonalizowanej polityki w Polsce relatywnie niedawno -

${ }^{3}$ Por. J. Jedlicki, Proces przeciwko miastu, „Teksty Drugie” 1991, nr 5; L. Mergler, K. Pobłocki, M. Wudarski, Anty-bezradnik przestrzenny: prawo do miasta $w$ dziataniu, Warszawa 2013, s. 20; J. Wasilewski, Społeczeństwo polskie, spoteczeństwo chtopskie, „Studia Socjologiczne” 1986, $\mathrm{nr}$ 1. Tę nie-miejskość oraz postchłopski kompleks wdrukowany w polską tożsamość znakomicie niedawno zdefiniowały dyskusje wokół sztuki teatralnej Moniki Strzępki i Pawła Demirskiego Wimie Jakuba $S$.

${ }^{4}$ Redefinicja tożsamości chłopskiej przez proletaryzację prowadziła niekiedy do ruralizacji miasta. Kwestie te omawia na przykładzie powojennej Łodzi Kacper Pobłocki; por. idem, Prawo do miasta i ruralizacja świadomości we wspótczesnej Polsce, w: M. Nowak, P. Pluciński (red.), O miejskiej sferze publicznej. Obywatelskość i konflikty o przestrzeń, Kraków 2011.

${ }^{5}$ Próby nadawania miastom określonych tożsamości: np. promowanie Poznania jako „miasta know-how”, inicjatywy na przecięciu administracji i trzeciego sektora, jak „Warszawa w budowie”, czy konstruowania Wrocławia jako „miasta spotkań”.

${ }^{6}$ Boom na (miejska) sztukę publiczna, wykorzystująca przestrzeń miasta jako tło lub tworzywo wypowiedzi; por. E. Rewers (red.), Miasto w sztuce - sztuka miasta, Kraków 2010.

${ }^{7}$ Mamy do czynienia z realną partycypacyjną erupcją. Konsultuje się dużo i często. Być może nawet zbyt wiele i zbyt często, jakkolwiek paradoksalnie to brzmi. 
w roku 2007/2008. Ich historia jest zatem krótka. Poza Polską MRS pojawiły się znacznie wcześniej, mniej więcej cztery dekady temu ${ }^{8}$.

Mimo że zasygnalizowałem właśnie „krótką historię” polskich MRS, ich korzeni możemy jednak doszukiwać się jeszcze w latach osiemdziesiątych, w działających wówczas politycznych ruchach protestu, z naciskiem na odradzający się wtedy $\mathrm{w}$ Polsce ruch (neo)anarchistyczny ${ }^{9}$. Jednym $\mathrm{z}$ jego głównych animatorów było trójmiejskie ugrupowanie nieformalne, Ruch Społeczeństwa Alternatywnego (RSA). Dotychczasowe, niezbyt liczne, opracowania poświęcone polskim MRS wątek ten w zasadzie ignoruja ${ }^{10}$. Co więcej, (neo)anarchistyczna tradycja radykalna ruchów miejskich zdaje się, że jest dzisiaj „wypierana” czy też marginalizowana. Na łamach organu wydawniczego RSA - ulotnego czasopisma „Homek”11 znaleźć możemy z kolei zaczyn tego, co uznać możemy za - zgodnie z dzisiejszym pojmowaniem tego pojęcia - projekt „demokracji miejskiej”, zatem i pewną zawarta w nim implicite ideę „prawa do miasta”. Ponadto, to przecież z kręgów anarchistycznych wywodzą się postulaty upowszechniania idei budżetu partycypacyjnego ${ }^{12}$, idei dziś coraz silniej sfunkcjonalizowanej ${ }^{13}$.

\footnotetext{
${ }^{8}$ Jeśli zaś uwzględnimy analizowany przez Castellsa ruch chilijskich pobladores, korzeni nowoczesnych ruchów miejskich możemy poszukiwać jeszcze w latach pięćdziesiątych XX w. M. Castells, Kwestia miejska, Warszawa 1982, s. 374-396; por. też: idem, Walka klas i sprzeczności miejskie. Pojawienie się społecznych ruchów miejskich w kapitalizmie monopolistycznym, w: B. Jałowiecki, S. Nurek (wyb.), Krytyka społeczeństwa kapitalistycznego w pracach socjologów zachodnich, Katowice 1979; idem, The City and the Grassroots. A Cross-cultural Theory of Urban Social Movements, London 1983; N. I. Fainstein, S. Fainstein, Urban Political Movements. The Search for Power by Minority Groups in American Cities, Englewood Cliffs - New Jersey 1974; S. Lowe, Urban Social Movements. The City after Castells, London 1986.

${ }^{9}$ Jest to jeden z silnych argumentów, który pozwala traktować w kategoriach obiektywnych ruchy (neo)anarchistyczne i lokatorskie jako ruchy miejskie, nawet jeśli dystansują się one od takiego samoopisu.

${ }_{10}$ Por. K. Czarnota, Prawo do miasta i polityka wysiedleń, „Le Monde Diplomatique” 2014, nr 9(103); K. Kurnicki, (Nowe) ruchy miejskie w Polsce - w stronę socjologicznego opisu, „Trzeci Sektor", nr 31, 2014; L. Mergler, O ruchach miejskich, czyli dla kogo jest miasto?, w: Ł. Bukowiecki, M. Obarska, X. Stańczyk (red.), Miasto na żqdanie. Aktywizm, polityki miejskie, doświadczenia, Warszawa 2014; K. Pobłocki, Magma ruchów miejskich, „Animacja Życia Publicznego. Zeszyty Centrum Badań Społeczności i Polityk Lokalnych” 2013, nr 3(10); K. Pobłocki, Nowa dekada, nowe miasto?, w: Ł. Bukowiecki, M. Obarska, X. Stańczyk (red.), op. cit.; M. Żakowska, Ruchy miejskie a tradycja ruchów społecznych, „Animacja Życia Publicznego. Zeszyty Centrum Badań Społeczności i Polityk Lokalnych” 2013, nr 3(10).

${ }_{11}$ Szczególnie istotne są tu dwa numery „Homka” (nr 43, 1989 oraz 44, 1990), Antyfuturyzm, czyli miasto dla człowieka oraz Miasto dla człowieka; por. Homek. Pismo Ruchu Społeczeństwa Alternatywnego 1983-1990, red. G. Berendt et al. Gdańsk 2013, s. 185, 196-197.

12 Jej zwolenników, jeszcze bez mała dekadę temu, traktowano jako zapatrzonych w alterglobalistyczne utopie radykałów; por. R. Górski, Bez państwa. Demokracja uczestniczqca w działaniu, Kraków 2007.

${ }^{13}$ G. Baiocchi, E. Ganuza, Participatory Budgeting as if Emancipation Mattered, „Politics and Society” 42, 2014, nr 1, s. 29-50. Część analiz przyjmuje jednak perspektywę zrywającą z myśleniem normatywnym i traktująca budżetowanie obywatelskie z perspektywy jego społecznych konsekwencji, że jest ono - nawet jeśli realizowane w plebiscytowej formie - pozytywnym elementem „procesu uczenia się” demokracji; por. R. Drozdowski, M. Frąckowiak, Bilans społecznej wyobraźni. Komentarz socjologiczny do Poznańskiego Budżetu Obywatelskiego, „Ruch Prawniczy, Ekonomiczny i Socjologiczny" 75, 2013, z. 4, s. 197-214.
} 
Współcześnie MRS nie stanowią jednolitej całości, mają wyraźnie hybrydowy charakter. W polu ruchów miejskich działają bowiem rozmaici aktorzy: (1) przywołane tu już ruchy (neo)anarchistyczne oraz powiąane z nimi (2) ruchy lokatorskie - konstytuujące socjalnie zorientowane skrzydło MRS; (3) dominujące w polu MRS ruchy mieszczańskie (niekiedy określane mianem „miejskich ruchów klasy średniej”) oraz (4) liczne słabiej zinstytucjonalizowane inicjatywy lokalne i (5) silnie zinstytucjonalizowane i działajace w polu „miejskich polityk” organizacje trzeciego sektora, obciażone wysokim ryzykiem quangoizacji ${ }^{14}$. Nie sposób też nie włączyć do analizy aktora coraz aktywniejszego, jakim są (6) partie polityczne. Te ostatnie nie są oczywiście w żaden sposób tożsame z MRS, niemniej dokonują coraz wyraźniejszych przechwyceń w ich polu. Bardziej szczegółowo podejmę ten problem dalej.

Co więcej, nie sposób w krótkim artykule podjąć szerzej wątek wskazanego zróżnicowania. Istnieją pierwsze opracowania na ten temat ${ }^{15}$. W dalszej części interesować mnie będzie przede wszystkim określony, węższy wycinek naszkicowanej całości - wątek dominujących w polu MRS „ruchów klasy średniej” oraz (1) ich relacje ze skrzydłem socjalnym ${ }^{16}$, przede wszystkim zaś (2) problem neutralizacji „polityczności” mieszczańskich MRS.

\section{RUCHY MIEJSKIE JAKO WYZWANIE DLA SOCJOLOGII RUCHÓW SPOŁECZNYCH}

Pojawienie się MRS na scenie obywatelskiego aktywizmu zaskoczyło nieco samych socjologów. Szybko okazało się też, że próby opisu, tym bardziej zaś wyjaśnienia fenomenu MRS, stawiaja pod znakiem zapytania klasyczne una-

${ }_{14}$ Powszechnie zwane QUANGOs (Quasi-Autonomous Non-Governmental Organisation; Quasi-Antonomous NGO) to rozpowszechnione szczególnie w Wielkiej Brytanii organizacje samorządowe prowadzące działania przede wszystkim w zakresie usług publicznych (zdrowie, edukacja), czyli zadania przypisane tradycyjnie państwu. Rząd deleguje zatem część uprawnień o charakterze władczym na rzecz QUANGOs. Organizacje te, formalnie przynależące do trzeciego sektora, postrzegane sa jako w istocie technokratyczne, nakierowane przede wszystkim na absorpcję środków publicznych oraz działające jak quasi-przedsiębiorstwa. Prócz QUANGOs wyróżnić też możemy tzw. GONGOs (Government Organized NGO), czyli organizacje bezpośrednio tworzone przez agendy rządowe, kontrolowane przez agendy rządowe oraz realizujące wytyczne i zadania polityki rządowej. Obie formy, szczególnie jednak pierwsza, wykorzystywania idei samoorganizacji i społeczeństwa obywatelskiego stanowia, zdaniem krytyków, istotne narzędzia w procesie „demontażu” państwa w duchu neoliberalnym oraz podają w wątpliwość ideę społecznej samoorganizacji. Wprowadzając sformułowanie „quangoizacja”, podkreślam tendencje technokratyczne, obecne w obrębie trzeciego sektora, w ramach którego, za parawanem idei społeczeństwa obywatelskiego, liczne organizacje działają w myśl logiki biznesowej. Jako jeden z niewielu polskich socjologów, w odniesieniu zaś do kwestii miejskiej bodaj jako jedyny, podejmuje ten problem Rafał Drozdowski; por. idem, Lepsza sfera publiczna - bezdyskusyjny postulat pod dyskusje, w: M. Nowak, P. Pluciński (red.), op. cit.

${ }_{15}$ K. Kurnicki, op. cit.; P. Pluciński, Miejskie (r)ewolucje. Radykalizm retoryki a praktyka reformy, „Praktyka Teoretyczna” 2013, nr 3.

${ }^{16}$ Czołowi działacze ruchów mieszczańskich wykluczają poza pole działania ruchów miejskich ruchy neoanarchistyczne. Dla przykładu, Lech Mergler postuluje: „Ruchy miejskie [...] nie jest to porozumienie pozamainstreamowych ruchów politycznych, takich jak: anarchiści, feminiści, alterglobaliści, zieloni [...]” - por. idem, op. cit., s. 90. 
rzędziowienie socjologiczne: zarówno dotyczące metody, jak i teorii. Chodzi zatem odpowiednio o kwestię prawomocności stricte obiektywistycznego (modelu) poznania w badaniach nad MRS oraz przyporządkowanie im adekwatnej, teoretycznej ramy interpretacyjnej. Rozpatrzę krótko obie kwestie.

\section{Miejskie praktyki społecznego (współ)wytwarzania wiedzy}

Badania MRS wiążą się z koniecznością rewizji ściśle obiektywistycznego paradygmatu poznania, a przynajmniej z potrzeba jego relatywizacji. W wypadku wielu współczesnych ruchów społecznych, miejskich zaś w szczególności, trudno stosować bowiem klasyczna, hierarchiczną perspektywę badany badacz, informator i „twórca wiedzy”. To, czego potrzebujemy, by dobrze rozumieć fenomen MRS, to założenia bliższe metodologii Alaine'a Touraine'a, dajace podwaliny pod participatory action research niż klasycznemu modelowi pozytywistycznemu ${ }^{17}$. Odpowiednia dla MRS jest zatem perspektywa bliższa zwrotowi performatywnemu w metodologii badań socjologicznych, zakładająca społeczne współwytwarzanie wiedzy ${ }^{18}$, w ramach której stosunek podmiotowo-przedmiotowy jest bliższy relacji horyzontalnej, oraz imperatyw zmiany społecznej, której wiedza akademicka ma służyć.

W przypadku polskich MRS jest to częściowo efekt dość aktywnego udziału w nich reprezentantów środowisk akademickich w MRS, którzy wchodza $\mathrm{w}$ role nie tylko eksperckie (zatem częściowo zewnętrzne, z ich roszczeniami do „obiektywizmu”), zajmując pozycje nie tylko „obserwatorów uczestniczących” czy „uczestników obserwujących”19, ale i otwarcie zaangażowanych aktywistów. Jak sugeruje Marek Nowak, sa to akademicy zajmujący przede wszystkim średnie lub niskie pozycje w hierarchii władzy uniwersytetów, $\mathrm{z}$, ,(1) typowym dla tej grupy nieco "socjalnym« światopoglądem; (2) charakterystycznym sposobem myślenia na temat projektowania zmian (próbami budowania systemu i ujęcia całościowego zagadnień) oraz (3) znaczacym poziomem deprywacji wynikajacym ze specyfiki finansowania szkolnictwa i słabej obecności sektora naukowego"20. Nawet jeśli w przypadku diagnozy Nowaka mamy do czynienia (w pewnym sensie) z samoopisem, dobrze określa on warunki współwytwarzania wiedzy na przecięciu akademii i miejskiego aktywizmu. Upraszczając: akademicy wytwarzają „myślenie teoretyczne”, opierając się na stanie wiedzy oraz dociekaniach empirycznych, z kolei aktywiści korzystają z „produktów” akademii jako istotnej zmiennej działania, zaplecza uprawomocniającego słuszność podejmowanych działań. Mamy zatem do czynienia z intensyfikacją procesu dwukierunkowej transmisji wiedzy, uruchomieniem

17 G. Chesters, Social Movements and the Ethics of Knowledge Production, „Social Movement Studies" 11, 2012, nr 2, s. 147.

18 Ibidem, s. 145-160; N. K. Denzin, Y. S. Lincoln, Metody badań jakościowych, t. 1 i 2, Warszawa 2009.

19 K. Pobłocki, Nowa dekada, nowe miasto?, w: Ł. Bukowiecki, M. Obarska, X. Stańczyk (red.), Miasto na żqdanie. Aktywizm, polityki miejskie, doświadczenia, Warszawa 2014, s. 57.

${ }^{20}$ M. Nowak, Środkowoeuropejski 'ruch miejski' jako ruch społeczny środkowych segmentów struktury społecznej AD 2014, w: P. Żuk (red.), O kulturze protestu jako rdzeniu tradycji europejskiej, Wydawnictwo Książka i Prasa, Warszawa 2015 (w druku, tekst udostępniony przez autora). 
procesów wzajemnego uczenia się i wzmożonej refleksyjności, ale i produkcja wiedzy dla szerszej publiczności.

Dobrym przykładem takiego właśnie korpusu wiedzy jest Anty-bezradnik przestrzenny. Czytamy w nim: „Pojęcia te nie powstawały przy biurku (choć część z nich zaczerpnęliśmy z akademickiej refleksji nad miastem) - są one przede wszystkim efektem naszej pracy i działania na rzecz miasta" ${ }^{21}$. Trudno w przypadku Anty-bezradnika dokonać prostej demarkacji pomiędzy wiedza akademicka a pozaakademicka, jego intencją jest przecież przekształcenie naukowej wiedzy na temat miasta i dynamiki ruchów społecznych w narzędzie realnej zmiany społecznej. Podobny, akademicko-aktywistyczny charakter ma wydana niedawno przez Wydawnictwa Uniwersytetu Warszawskiego publikacja Miasto na żadanie ${ }^{22}$.

\section{W poszukiwaniu teorii miejskich ruchów społecznych}

Drugą konsekwencją dla socjologii ruchów społecznych jest prawdopodobna konieczność (re)konstrukcji modeli teoretycznych wyjaśniających funkcjonowanie ruchów miejskich. Pole badań nad MRS nie jest bowiem zaspodarowane wyłącznie przez socjologów, ale w dużej mierze przez innych reprezentantów nauk społecznych: kulturoznawców czy antropologów, poza nimi zaś przede wszystkim przez geografów społecznych czy też reprezentantów urban studies ${ }^{23}$.

Sama socjologia nie wypracowała zatem odrębnej teorii MRS. Wynikać to może częściowo z ich hybrydowości. Otwarte pozostawię pytanie, czy taka nowa teoria MRS jest socjologii w ogóle potrzebna. Może bowiem wystarczy nam, by dokonywać rzetelnego opisu i wyjaśnienia, hybrydowy - jak sam ruch teoretyczny bricolage?

Badając MRS, odnosić się zatem musimy przede wszystkim do dostępnych, ogólnosocjologicznych założeń oraz tradycji badań ruchów społecznych. W konsekwencji w badaniach MRS stosuje się narzędzia analizy właściwe zarówno badaniom tzw. starych $^{24}$, jak i nowych ruchów społecznych (NRS), przy założeniu, że to właśnie teoria NRS jest dominująca perspektywą analityczna ruchów miejskich ${ }^{25}$, w istotnych miejscach wymagająca jednak uzupełnień.

Perspektywa NRS - jako wyrastająca z określonego doświadczenia historycznego, przede wszystkim erupcji kontrkultury i kulturowej rewolu-

${ }^{21}$ L. Mergler, K. Pobłocki, M. Wudarski, op. cit.

${ }^{22}$ Ł. Bukowiecki, M. Obarska, X. Stańczyk (red.), Miasto na żadanie. Aktywizm, polityki miejskie, doświadczenia, Warszawa 2014.

${ }^{23}$ C. Pickvance, From Urban Social Movements to Urban Movements: A Review and Introduction to a Symposium on Urban Movements, „International Journal of Urban and Regional Research" 27, 2003, nr 1, s. 104.

${ }^{24}$ Szczególnie jeśli będziemy pojmować je jako ruchy definiujące się „materialistycznie” czy też radykalnie redystrybucyjne w duchu Lefebvre'a i wczesnego Castellsa

${ }^{25}$ Por. S. M. Buechler, Teorie nowych ruchów społecznych, w: K. Gorlach, P. H. Mooney (red.), Dynamika życia społecznego. Wspótczesne koncepcje ruchów społecznych, Warszawa 2008; C. Offe, Nowe ruchy spoteczne - przekraczanie granic polityki instytucjonalnej, w: P. Sztompka, M. Kucia (red.), Socjologia. Lektury, Kraków 2005; C. Pickvance, op. cit., s. 104. 
cji soixante-huitards - skupia się bowiem silniej na „momencie utopijnym” ruchów społecznych: antysystemowym i spontanicznym, nieformalnym, horyzontalnym i niezinstytucjonalizowanym charakterze działań oddolnych. $\mathrm{O}$ ile zatem ruchy MRS sa ruchami protestu, a taka jest geneza dużej części z nich, o tyle perspektywa NRS wydaje się adekwatna. Staje się jednak coraz mniej użyteczna, im silniej MRS się instytucjonalizują: im częściej przyjmują sformalizowane postaci organizacyjne, najczęściej stowarzyszeniowe (brnąc nierzadko w stronę quangoizacji), im silniej stają się wyrazicielami koncyliacyjnych strategii działania, coraz bliżej współpracując z władzami samorządowymi, wreszcie, w przypadku już samych aktywistówgodząc „karierę aktywistystyczną” z urzędnicza, a nawet otwartym akcesem partyjnym.

Przywołane problemy, związane z - ujmijmy to metaforycznie - organizacją w ruchu lepiej wyjaśniają ujęcia alternatywne względem teorii NRS, przede wszystkim perspektywa mobilizacji zasobów, a nawet teorie organizacji, również wpływowe w polu teoretycznym ruchów społecznych ${ }^{26}$. Perspektywa ta również nie jest bezproblemowa: nie odpowiada bowiem precyzyjnie na pytanie, jak dalece może instytucjonalizować się ruch społeczny, by ciagle pozostać ruchem; nie definiuje zatem granicy, po przekroczeniu której mamy już do czynienia z utratą dynamiki czy organizacyjną hipertrofia, przeczącymi „ruchowi” w „organizacji”. Teoria ruchu społecznego musi bowiem w tym momencie zmierzyć się z problemem „oligarchizacji”. Jeśli zrobi to źle albo przeoczy ten moment, pociagnie to za soba niebezpieczeństwo, że zamiast o ruchach społecznych, językiem teorii ruchów społecznych - choć w zasadzie zafałszowanym - będziemy mówić o zwyczajnych grupach interesu czy też o quasi-przedsiębiorstwach.

Kwestii stojącej przed nami alternatywy: konieczności konstruowania teorii MRS albo jako nowej i odrębnej, albo też jako wyłącznie hybrydowej - oczywiście nie rozstrzygnę w tym miejscu. Niemniej jej postawienie jako problemu do rozwiązania jest, moim zdaniem, istotne.

Obecnie najsilniejszym bodaj kryterium identyfikacji MRS, pozwalającym traktować je na gruncie socjologicznych teorii ruchów społecznych jako odrębny fenomen, pozostaje względnie spójny kontekst ideowy, do którego się odwołuja. Idzie przede wszystkim o idee prawa do miasta, demokracji miejskiej (urban democracy) oraz niekiedy sprawiedliwości przestrzennej (spatial justice). Stanowią one przy tym nie tylko narzędzia opisu rzeczywistości, ale przede wszystkim instrumenty skutecznego działania. To właśnie one, przede wszystkim ich historycznie określona zmienność oraz praktyki interpretacyjne, wytwarzają MRS jako relatywnie jednolity, z całym wewnętrznym zróżnicowaniem, podmiot miejskiej zmiany i hybrydową to ż-

${ }^{26}$ Por. B. S. Caniglia, J. Carmin, Badania organizacji ruchów spotecznych: klasyczne perspektywy $i$ nowe trendy, w: K. Gorlach, P. H. Mooney (red.), Dynamika życia społecznego. Wspótczesne koncepcje ruchów społecznych, Warszawa 2008; B. Klandermans, S. Tarrow, Mobilizacja w ruchach społecznych: o syntezie koncepcji europejskich $i$ amerykańskich, w: K. Gorlach, P. H. Mooney (red.), op. cit. 
sa mość polityczną ruchów, przez którą rozumiem procesy autodefinicyjne, polegajacce na budowaniu wewnętrznej spójności, konstruowaniu „ideologicznego my” rozmaitych frakcji $\mathrm{MRS}^{27}$.

\section{SILA POLITYCZNYCH TOŻSAMOŚCI, CZYLI O PODZIAŁACH RAZ JESZCZE}

W dużym uproszczeniu wskazać możemy na kluczowe trajektorie podziałów w ramach MRS, przebiegające wzdłuż dość tradycyjnych, antynomicznie zorientowanych kategorii, takich jak: lewica-prawica, radykalizm-reformizm czy socjalizm-liberalizm. Kategorie te, przynajmniej ich część, były już wprawdzie wielokrotnie odwoływane, przypisywano im bezużyteczność, a nawet moce mistyfikujące rzeczywistość. Niektóre spośród tych krytyk są częściowo prawomocne, co jednak nie zmienia faktu, że same przywołane kategorie sa dyskursywnie żywe, definiują przy tym cały czas tożsamości polityczne.

Zatem jeśli przypiszemy im, przy całej historycznej zmienności, adekwatność, okazuje się, że za ich pomocą możemy zrekonstruować główną linię demarkacyjna w ramach polskich $\mathrm{MRS}^{28}$. Z jednej strony mamy zatem ruchy (neo)anarchistyczne i lokatorskie - autodefiniujace się jako lewicowe i socjalne, odwołujace do „radykalnych” strategii i tak też, genetycznie, w zasadzie postmarksistowsko odczytujące idee RTTC ${ }^{29}$, „demokracji miejskiej” czy „sprawiedliwości przestrzennej”.

Z drugiej strony mamy ruchy niekoniecznie przecież prawicowe, na pewno jednak nastawione liberalnie i reformistycznie. Sa to przede wszystkim rozmaite, przywołane już tu z nazwy, „ruchy mieszczańskie” czy też „ruchy klasy średniej”, dla których idea RTTC jest niczym innym, jak „pustym znaczącym” w sensie, jaki temu pojęciu nadał Ernesto Laclau ${ }^{30}$. Ich reformatorska logika oraz retoryka „neutralności”, werbalnie odżegnująca się od „ideologicznych” uwikłań, pozwala im wchodzić w system głębiej. Bliższa jest też racji bytu aktywnie działajaccych w polu MRS i silnie zinstytucjonalizowanych NGOs, niekiedy wręcz QUANGOs.

Ten postępujący proces polityczno-tożsamościowej klaryfikacji wzmocniły niedawne wybory samorządowe, do których przystapiła pewna tylko, wywodzą-

27 Por. P. Pluciński, op. cit.

28 Ibidem, s. 144-147.

29 Por. H Lefebvre, Prawo do miasta, „Praktyka Teoretyczna” 2012, nr 5, http://www.praktykateoretyczna.pl/PT_nr5_2012_Logika_sensu/14.Lefebvre.pdf (dostęp: 22.12.2014).

${ }^{30}$ Pisze o tym zresztą również David Harvey w swoim Buncie miast: „Prawo do miasta jest pustym znaczącym pełnym immanentnych, ale nie transcendentnych właściwości. Nie oznacza to, że jest nieważne i politycznie bezsilne; wszystko zależy od tego, komu uda się napełnić owo znaczące rewolucyjnym, przeciwstawnym reformistycznemu, znaczeniem" (idem, Bunt miast: Prawo do miasta i miejska rewolucja, Warszawa 2012, s. 186-187). Problem ten doskonale obrazuje też dyskusja wokół przywołanej książki; por. Jaki bunt? Jakich miast?, „Przekrój” 2012, nr 32/33, s. 8-12. 
ca się w zasadzie głównie z frakcji „mieszczańskiej”, część MRS ${ }^{31}$, zorganizowana w ramach tzw. Porozumienia Ruchów Miejskich (PRM). Powstanie tego ciała miało na celu utrzymanie ,apolitycznego” charakteru już istniejącej sieci, jaką jest luźno i sieciowo zorganizowany Kongres Ruchów Miejskich. Przede wszystkim środowiska radykalizujące, ale i część podmiotów chcących działać dalej wyłącznie „ekspercko” (np. poznańskie Inwestycje dla Poznania, katowickie Napraw Sobie Miasto czy wrocławskie Towarzystwo Upiększania Miasta Wrocławia), odrzuciły perspektywę wyborczego wejścia w system.

\section{CZY KRYZYS MIEJSKICH RUCHÓW SPOŁECZNYCH JEST NIEUNIKNIONY?}

Wybory samorządowe, które okazały się częściowym sukcesem MRS, unaoczniły kilka problemów. Po pierwsze, uwydatniły problem politycznego samookreślenia MRS. Po drugie, zrodziły wątpliwości, czy - jeśli tak, to co będzie to oznaczało? - po świadomym wejściu w system polityczny MRS mogą stać się ofiarami swojego sukcesu. Innymi słowy, czy zinstytucjonalizują się tak bardzo, że zgubią moment „ruchu” w „organizacji”. Czy, mówiąc metaforycznym językiem Habermasa, nastapi wyczerpywanie się energii utopijnych ${ }^{32}$ i ich systemowe przejęcie?

Pierwszy problem dotyczy niejednoznacznej polityczności MRS. Kluczowa jest tu deklaracja „apolityczności”, jaką wyrażają dwie podstawowe idee: koncepcja „narracji konkretnych” oraz będący jej częściowym rozwinięciem „miastopogląd”33. Ten ostatni zresztą stał się jedna z kluczowych kategorii legitymizujacych start w wyborach samorządowych ${ }^{34}$.

Idea „narracji konkretnych”, opracowana przez Kacpra Pobłockiego i Lecha Merglera (przedstawiona w książce napisanej wspólnie z Maciejem Wudarskim), jest próbą myślenia aideologicznego, wyrastającą z przekonania, że polityczne oznacza partyjne. Oczywiście, w deklaracji apolityczności chodzi nie tyle o deklarację „wolności od polityki”, ile raczej o wyraźny dystans wobec jej parlamentarnego i zinstytucjonalizowanego, również na poziomie lokalnym, charakteru $^{35}$. Idzie zatem o to, by wyraźnie rozdzielać społeczny i polityczny charakter działań.

31 Jedynym poważnym wyjątkiem jest tu silny ruch „Kraków Przeciwko Igrzyskom” (KPI), definiujący się otwarcie w kategoriach socjalnych i „,nowolewicowych”, którego przypadek wymagałby w zasadzie osobnej analizy.

32 J. Habermas, Kryzys państwa dobrobytu i wyczerpywanie się energii utopijnych, „Colloquia Communia” 1986, nr 4-5 (27-28).

${ }^{33}$ Co istotne, to poszukiwanie ,ideologicznej” czy też politycznej czystości prowadzi do wykluczeń - poza polem MRS lokowane są bowiem określone ruchy o stricte miejskim charakterze; por. wyżej, przypis 16 .

${ }^{34}$ K. Pobłocki, Wskrzeszenie człowieka publicznego [polemika], „Dziennik Opinii”, http://www. krytykapolityczna.pl/artykuly/miasto/20141219/poblocki-wskrzeszenie-czlowieka-publicznego-polemika (dostęp: 22.12.2014).

${ }^{35}$ L. Mergler, op. cit., s. 92. 
Interesem narracji konkretnych jest dystansowanie się wobec oficjalnych partii politycznych - głównie partii władzy, ale też otwarcie politycznych (innymi słowy: niepróbujacych maskować politycznego uwikłania oraz „usytuowanego" interesu, jaki reprezentuja), przy tym jednak odżegnujących się od walk o zinstytucjonalizowaną reprezentację, radykalnych ruchów społecznych, szczególnie zaś aktywnie działających w polu MRS ugrupowań neoanarchistycznych. W tym pierwszym przypadku chodzi przede wszystkim o poszukiwanie platformy wspólnych działań, łączącej ludzi o rozmaitych, w domyśle radykalnie niekiedy odmiennych, poglądach politycznych. Ta „ekumeniczna” strategia zasypywania różnic ma być w istocie ponadideologicznym spoiwem, podtrzymującym „miejską” tożsamość ruchów. Z perspektywy socjologicznej ma być zatem narracją więziotwórcza, zapewniająca aktywistycznej wspólnocie pewną przynajmniej, momentami pewnie chwiejna czy przygodna, ale jednak realna, spójność. Przy czym trzeba pamiętać, że jej otwartość nie jest tożsama z pełnym pluralizmem, definiuje jednak bowiem określone ruchy jako „nie-miejskie”.

Filozoficznym zapleczem idei narracji konkretnych jest zmierzch narracji ideologicznych. Jej autorzy wyrażają przekonanie, że nie wyznaczają one dziś sensu politycznego zaangażowania. Oddajmy im głos: „Istnieją historycznie trzy wielkie narracje ideologiczno-polityczne: socjalizm, liberalizm, konserwatyzm. W różnych wariantach, konfiguracjach i proporcjach rozstrzygają one w swoich opowieściach o tym, kim jest człowiek, społeczeństwo, gospodarka, polityka, władza, wolność i inne podstawowe wartości oraz strategie działania na ich rzecz. [...] Ruchy miejskie korzystaja z wielkich narracji, gdy jest to produktywne dla rozwiązywania takich właśnie wymiernych problemów. Na przykład myśl liberalna bywa pomocna w problemach gospodarczych, lewicowa $\mathrm{w}$ sprawach społecznych, ekologiczna w kwestiach zrównoważonego rozwoju" 36 .

Idea narracji konkretnej ma się zatem realizować przez możliwość (a)ideologicznej neutralności, zdolność do abstrahowania od politycznych partykularyzmów. Czy nie jest ona jednak zawoalowana postacia postpolitycznych obietnic? Myślenie „narracją konkretną” opiera się bowiem na przekonaniu, że „podziały na "prawicę» i »lewicę», ukształtowane głównie w wieku XX, są przestarzałe i nie odpowiadają realnym podziałom we współczesnym społeczeństwie" ${ }^{37}$. Oczywiście, konstytutywny dla nowoczesności podział na lewicę i prawicę niekiedy więcej mistyfikuje, niż wyjaśnia, trudno jednak sądzić, by ten stary „esencjalizm” całkowicie stracił rację bytu. Dopóki bowiem horyzont nowoczesności wyznaczany jest przez stosunki kapitalistyczne, a nierówności społeczne i mechanizmy ekskluzji są immanentnie w nie wpisane, dopóty idee określane zwyczajowo, niekiedy nawet obiegowo, mianem lewicowych maja rację bytu.

Możemy pytać dalej: Czy narracje konkretne, nawet jeśli realizują określone, bardzo istotne przecież funkcje więziotwórcze, nie są same postacią myślenia ideologicznego? Przedstawiając się bowiem jako uniwersalistyczne, w isto-

${ }^{36}$ L. Mergler, K. Pobłocki, M. Wudarski, op. cit., s. 38.

${ }^{37}$ Ibidem, s. 37. 
cie nie są w pełni otwarte. Elementarna socjologiczna podejrzliwość, w zasadzie niewykraczająca daleko poza podręcznikowe pojmowanie socjologii wiedzy w duchu Karla Mannheima, każe nam bowiem pamiętać, że określone postaci myślenia, szczególnie te roszczące sobie prawo do uniwersalizmu, bywają otwarcie partykularne. I dalej, już porzucając Mannheimowskie tropy, warto mieć na uwadze, że „neutralność” jako „ideologiczna pustka” w sensie empirycznym, konkretnie zaś historycznego rozwoju systemów społecznych, nie istnieje. Horyzont naszego (późno)nowoczesnego myślenia wyznacza bowiem, nawet jeśli jest adwersarzem, ideologia liberalna ${ }^{38}$. „Narracje konkretne” oraz „miastopogląd” jako ideologicznie „transparentne” w rzeczywistości uruchamiają zatem gry w polu liberalizmu i na jego zasadach. Mogą być przy tym przechwytywane również przez inne, bynajmniej nie neutralne, siły polityczne ${ }^{39}$.

\section{V. „DZISIAJ WSZYSCY JESTEŚMY Z RUCHÓW MIEJSKICH”", CZYLI O RYZYKU PRZECHWYCEŃ}

Mówiąc o przechwyceniach, zdać sobie należy na samym wstępie sprawę, że nie wszystkie z nich muszą mieć „wrogi” charakter, spoglądać na nie można „dialektycznie”: definiując różne rodzaje ryzyka, ale i szanse z nimi związane.

Wejście w system dość szybko zrewidowało przekonanie o apolitycznej transparentności, obnażając podatność „miastopoglądu” na przechwycenia o cynicznym charakterze. Paradygmatyczny jest tu przypadek ruchu Miasto Jest Nasze (MJN), który wprowadził do rady dzielnicy warszawskiego Śródmieścia czterech radnych ${ }^{41}$. Krótko po wyborach, w atmosferze wzajemnych być może sprokurowanych - oskarżeń, klub MJN opuściło aż trzech radnych, szybko wchodzac w koalicje $\mathrm{z}$ największymi klubami partyjnymi w stolicy: Platformy Obywatelskiej oraz Prawa i Sprawiedliwości ${ }^{42}$. Wywołało to oczywiście wrzenie w aktywistycznym środowisku, o dezorientacji i rozczarowaniu wyborców nie wspominając. Nie miejsce tu, by relacjonować dyskursywne reakcje $\mathrm{e}^{43}$. Najistotniejszy jest tu problem samych „narracji konkretnych”,

${ }^{38}$ I. Wallerstein, The Modern World-System, t. 4: Centrist Liberalism Triumphant 1789-1914, Berkeley-Los Angeles-London 2011.

39 Taki mocny zarzut stawia Joanna Erbel; por. eadem, Ruchy miejskie nie chca być konserwa 2.0, http://www.krytykapolityczna.pl/artykuly/miasto/20141211/erbel-nastepny-ruch-ruchow-kongres-w-slupsku (dostęp: 15.12.2014).

${ }^{40}$ Przytoczone tu z pamięci sformułowanie to zdystansowany, ironiczny komentarz jednego z aktywistów po sukcesie w wyborach lokalnych opublikowany w portalu Facebook.

41 Był to bodaj największy - po wyborze na prezydenta Gorzowa Wielkopolskiego Jacka Wójcickiego, reprezentującego stowarzyszenie „Ludzie dla Miasta” - sukces wyborczy w ramach ogólnopolskich struktur PRM.

${ }^{42}$ Por. W. Karpieszuk, Koniec koalicji PO-MJN w Śródmieściu. Wiceburmistrz od postanki Pawłowicz, http://warszawa.gazeta.pl/warszawa/1,34862,17141446,Koniec_koalicji_PO_MJN_w_ Srodmiesciu_Wiceburmistrz.html (dostęp: 4.01.2015); Oświadczenie członków Miasto Jest Nasze, http://miastojestnasze.org/oswiadczenie-czlonkow-miasto-jest-nasze/ (dostęp: 4.01.2015).

${ }_{43}$ Por. J. Erbel, op. cit.; K. Pobłocki, Wskrzeszenie człowieka publicznego [polemika], op. cit.; W. Kacperski, Po co nam ruchy miejskie po wyborach, „Kultura Liberalna”, http://kulturaliberalna. pl/2014/12/22/ruchy-miejskie-wybory-samorzadowe/ (dostęp: 27.12.2014). 
których pluralistyczne (ergo liberalne), próbujace zawieszać myślenie w kategoriach „mocnych” tożsamości politycznych, założenia nie wytwarzaja jednocześnie skutecznych mechanizmów selekcji i kontroli nad „wykonaniem” przypisanej roli „apolitycznego reprezentanta”, umożliwiając jej nieprawomocną redefinicję.

Eksces ten, jak mogłoby się wydawać na pierwszy rzut oka, przy bliższym nieco oglądzie wcale nie zdaje się aż tak partykularny. Wpisuje się bowiem $\mathrm{w}$ ramy procesu penetracji środowisk MRS przez partie polityczne ${ }^{44}$. Jest to proces in statu nascendi. Trudno w tym przypadku o twarde twierdzenia, możliwe sa tylko hipotezy. Jest przy tym procesem bardzo niejednoznacznym, w ramach którego zaznacza się kilka tendencji.

Pierwsza z nich to otwarty alians partii politycznych i aktywistów MRS. Strategię tę przyjęła polska Partia Zielonych - co jest tu istotne, niebędąca partią władzy, słabo zinstytucjonalizowana, wywodząca się i cały czas nawiązująca do aktywistycznego etosu ${ }^{45}$. Spotkało się to zresztą w znacznej mierze z negatywną reakcją ze strony środowisk MRS, szczególnie w kontekście kandydatury Joanny Erbel na prezydentkę stolicy. Krok Erbel jest jednak w pewnej mierze symboliczny, w samym środowisku MRS zaczęły się bowiem pojawiać głosy o konieczności powołania autonomicznej „partii miejskiej”.

Druga możliwość to „sięganie po aktywizm/aktywistów”, przede wszystkim zaś po stojące za nimi poparcie partii władzy. Chodzi o takie sposoby sprawowania lub też pozyskiwania władzy, które realizuja się za pomocą pośredniego, dzięki zapleczu MRS, mobilizowania społecznej energii. Jacek Jaśkowiak w Poznaniu to twarz lokalnego ruchu miejskiego z poprzednich wyborów samorządowych, Robert Biedroń w Słupsku z kolei przechwycił realne potrzeby mieszkańców - doskonale sublimował społeczne oczekiwania i potrafił zagospodarować je za pomoca zasobów partyjnych. Wreszcie, do MRS i ich elektoratu odwoływali się w drugiej turze kandydaci na prezydentów i prezydentki Warszawy $^{46}$ i Wrocławia ${ }^{47}$. Oczywiście, o ile „sięganie po aktywistów” przez Jaśkowiaka czy Biedronia możemy definiować jako w pewien sposób naturalne (w przeciwieństwie do pozostającej w otwartym konflikcie z MRS Hanny Gronkiewicz-Waltz), o tyle uruchamia ono jednak określony precedens oraz otwiera przestrzeń do wrogich przechwyceń.

${ }^{44}$ Prawdopodobnym początkiem podobnego sposobu myślenia miała być niezrealizowana inicjatywa kilku prezydentów polskich miast: „Obywatele do Senatu”. W zamyśle chcieli oni „,stworzyć" ruch społeczny, przypatrując się już wówczas rosnącym w siłę MRS; por. P. Pluciński, Przeciw dzikiej urbanizacji, „Przegląd” 2011, nr 30, s. 49.

45 P. Gliński, Polscy Zieloni. Ruch społeczny w okresie przemian, Warszawa 1996.

${ }^{46}$ P. Gawlik, Wybory 2014: Kandydaci kusza aktywistów. Ci nie daja się nabrać, http://wyborcza.pl/1,141483,17022191,Wybory_2014_Kandydaci_kusza_aktywistow_Ci_nie_daja.html (dostęp: 7.12.2014).

${ }^{47}$ Tak swoje próby charakteryzował Rafał Dutkiewicz: „Na przykład ruchy miejskie, które uważam za bardzo pozytywny element politycznego krajobrazu, ale które z natury rzeczy są zawsze kontestujące. Z tego powodu nie udało mi się przeciągnąć ich na swoją stronę"; J. Harłukowicz, Sensacyjne wyznania Dutkiewicza. Mogłem być wicepremierem, http://wroclaw.gazeta.pl/wr oclaw/1,35771,17079365,Sensacyjne_wyznania_Dutkiewicza_Moglem_byc_wicepremierem.html (dostęp: 4.01.2015). 
Trzecia ewentualność to wreszcie przechwytywanie retoryki, nie zaś samych aktywistów czy też związanych z nimi środowisk poparcia. I to przechwycenie może być interpretowane niejednoznacznie: $\mathrm{z}$ jednej bowiem strony możemy mieć do czynienia z trywializacją określonych konceptów - takie zarzuty są niekiedy wysuwane wobec instrumentalizacji idei budżetów partycypacyjnych czy konsultacji społecznych ${ }^{48}$. Z drugiej jednak strony możemy traktować przechwytywanie narracji czy też miejskich dyskursów jako element procesów wzajemnego uczenia się. Tak ujmuje to - właśnie jako szansę! - Wojciech Kacperski: „Największym sukcesem ruchów miejskich, także tych, które wystartowały w wyborach, jest zmiana narracji na temat polskich miast. Ten sukces nie powinien zostać zaprzepaszczony" ${ }^{49}$. Owa zmiana narracji, czy też przechwytywanie miejskich dyskursów, jest w pewnym sensie reformistyczna postacią wnoszenia świadomości, sukcesem jest zaś zmiana narracji, skłonienie aspirujacych lub pełniących funkcje władzowe do nieinstrumentalnego, rozumiejącego włączania obywatelskich postulatów w ramy lokalnych programów politycznych. Powinnością MRS zaś jest permanentna społeczna kontrola ich realizacji. W tym przypadku mamy więc do czynienia $\mathrm{z}$ „samoograniczająca się miejską rewolucja”, funkcjonalną korektą systemu, tak jak pojmował ją choćby Ralph Dahrendorf ${ }^{50}$. Pewna część środowisk miejskich postuluje konieczność „zatrzymania się” MRS w tym właśnie miejscu.

Zarzuty na temat regresywnego (czy konserwatywnego, co utożsamia się też z dyspozycją prawicowa) charakteru polskich MRS spotkać mogliśmy jednak jeszcze na długo przed wyborami samorządowymi. Formułował je m.in. Xawery Stańczyk ${ }^{51}$. Nie wydaje się jednak, by MRS były konserwatywne w esencjalistyczny sposób, ich pole jest bowiem nazbyt złożone. Jakkolwiek zatem konserwatyzm MRS nie jest ich naturalną dyspozycją (w odróżnieniu od ideologii lewicowej, z której MRS i idea RTTC genetycznie wyrastaja), mogą być one jednak przez siły konserwatywne przechwytywane. Interesowały mnie w tym kontekście następujace zagrożenia: (1) postpolityczne pokusy wpisane w ideę narracji konkretnych, które legitymizują ucieczkę od konieczności politycznego samookreślenia oraz stanowią ich konsekwencję (2) procesy wykluczania poza pole MRS pewnych jej segmentów, głównie „ruchów radykalnych”. To właśnie te elementy czynią pole MRS otwartym na niebezpieczeństwo przechwyceń o instrumentalnym charakterze.

${ }^{48}$ Ryszard Grobelny, powszechnie oskarżany o taką właśnie instrumentalizację, pytany o fenomen MRS i rolę zaangażowania obywatelskiego odpowiedział: „W jakimś sensie sam je wykreowałem. Jestem jedynym prezydentem w kraju, który bardzo silnie zabiega o wzrost znaczenia konsultacji społecznych. Konsultacje oznaczaja, że wzrasta u mieszkańców świadomość wpływu na rzeczywistość. Rozbudowany system konsultacji powoduje, że pojawia się grupa mieszkańców, którzy mają inne wymagania”; por. P. Bojarski, S. Lipoński, Grobelny: Będq o mnie pisać jak o Cy. rylu Ratajskim, http://wyborcza.pl/1,141483,17079516,Grobelny_Beda_o_mnie_pisac_jak_o_Cyrylu_Ratajskim.html (dostęp: 7.12.2014).

${ }^{49}$ W. Kacperski, op. cit.

${ }^{50}$ R. Dahrendorf, Klasy i konflikt klasowy w społeczeństwie przemysłowym, Kraków 2008, s. 206

${ }^{51}$ X. Stańczyk, Konserwa u bram, w: Ł. Bukowiecki, M. Obarska, X. Stańczyk (red.), op. cit. 


\section{FORPOCZTA ALTERMODERNIZACJI}

$\mathrm{Na}$ zakończenie warto wrócić do definiowanego na początku artykułu zróżnicowania w ramach MRS. Pole MRS jest bowiem (albo myśląc normatywnie: powinno być) w rzeczywistości hybrydowe. MRS istnieją i sa silne dzięki swojemu zróżnicowaniu: ideowemu, organizacyjnemu, strategicznemu. Ruch istnieje dzięki wielości ruchów w jego ramach. Tendencje radykalne zapobiegaja zastyganiu ruchu, siłom reformatorskim łatwiej z kolei dokonywać pragmatycznych korekt systemu. W tak pojmowanym ruchu toczą się bowiem walki społeczne, których horyzontem jest bardzo różnorodnie pojmowana wizja „dobrze urządzonej wspólnoty lokalnej”. Jednym z aktorów tej walki stają coraz wyraźniej zinstytucjonalizowane podmioty, przede wszystkim partie polityczne, próbujące przechwytywać „energie utopijne”. Przed MRS stoi zatem pytanie o ich polityczną tożsamość: Jak daleko chca wchodzić w system i w jaki sposób pojmować zamierzają instytucjonalizację? Niemniej definiowanie samych siebie w kategoriach „pluralistycznego agonizmu" wydaje się szansa na to, by ruchy pozostały ruchami, innymi słowy by jak najdłużej opierały się niezłomnej regule Michelsowskiego „żelaznego prawa oligarchii" ${ }^{2}$.

To, co łączy wszystkie - mocno zróżnicowane przecież - siły konstytuujące MRS, zarówno te radykalne, jak i reformistyczne, to fakt, że wszystkie one sa ruchami stricte nowoczesnymi, z definicji miastocentrycznymi, niewikłającymi się ideologię „neoluddyzmu”. Żądaja zerwania z pułapkami modernizacji monologowej, administrowanej; poszukuja miasta uspołecznionego, w ramach logiki, mówiąc raz jeszcze językiem Habermasa, „racjonalności zdecentrowanej”. Reprezentanci MRS rozniecaja zatem, jak to określiłem, altermodernizacyjną iskrę.

Modernizacyjny potencjał MRS z jednej strony musi brać pod uwagę ograniczenia postsocjalizmu, z drugiej strony - jeszcze chyba silniej - uwikłany jest $\mathrm{w}$ niespełnione obietnice ładu neoliberalnego. MRS stanowia zatem oddolna, obywatelską odpowiedź na wyczerpywanie się narracji modernizacji transformacyjnej ${ }^{53}$. Podobne intuicje wyraża zresztą Nowak, pisząc: „Ideologie współczesnego polskiego ruchu miejskiego (wydaje się, że można to spostrzeżenie również uogólnić na środowiska środkowoeuropejskich ruchów miejskich w ogóle) da się paradoksalnie opisać jako późno-nowoczesny progresywizm zorientowany na rozwój zrównoważony. Ta dość szczególna zbitka jest trudna do zrozumienia bez odwołań do wskazanych na początku odniesień do ideologii transformacji i teorii zależności. Ramą konceptualizacyjną są uniwersalne procesy, które przewartościowują tradycyjne (nowoczesne) myślenie o mieście" ${ }^{54}$.

Potencjał MRS to zatem potencjał al term odernizacyjn y. Taki bowiem charakter maja radykalne postulaty redefinicji pojmowania własności w wy-

${ }^{52}$ B. S. Caniglia, J. Carmin, op. cit., s. 100.

${ }^{53}$ G. Röhrborn, Od partycypacji do polityzacji, „Miasta” 2013, nr 3-4(5-6), s. 64.

${ }^{54}$ M. Nowak, op. cit. 
niku gier z systemem podejmowane przez ruchy (neo)anarchistyczny i lokatorski; taki charakter mają żądania szerszego i bardziej aktywnego włączania się władzy publicznej jako aktywnego podmiotu - dostarczyciela usług i dóbr publicznych czy redefinicji realnego kapitalizmu w kierunku jego większej „wrażliwości społecznej”; taki wreszcie charakter mają „radykalne” żądania prawa do realnego współzarządzania miastem, obywatelskiej kontroli i polityki włączania obywateli w procesy sprawowania władzy. Stawek, o które toczy się walka, można by zresztą zdefiniować o wiele więcej, nawet jeśli nie wszystkie miałyby tę samą wartość.

Co tu jest jednak najważniejsze? Konkludując: nieinstrumentalne przejęcie i włączanie tak pojmowanych postulatów w ramy programów lokalnych władz sami aktywiści postrzegają bowiem najczęściej jako swoje rzeczywiste zwycięstwo. Być może zatem dalsze zwycięstwa, w tym wyborcze, znaczyć będa ścieżkę powolnego, ale sukcesywnego uwiądu ruchów.

dr Przemystaw Pluciński

Uniwersytet im. Adama Mickiewicza w Poznaniu

plucin@amu.edu.pl

THE BETTER, THE WORSE, OR A SPECTRE OF A CRISIS

OF URBAN SOCIAL MOVEMENTS?

Sum mary

Urban social movements have been increasingly present in the public sphere, as well as at the very core of political debate in contemporary Poland. Some of them have also moved towards institutionalized politics, expressing growing political ambitions. The litmus test of this process were recent local elections. The political strategy of 'entering the system,' which takes place in some cases, may be a turning point in the logic of political development of Polish urban social movements.

The paper examines some of the most crucial problems it raises. Two of them deal with essential problems of sociology itself: firstly, with the construction of the theory of (urban) social movements and secondly, with the problem of social (co)production of knowledge. The third issue concerns the possible crisis of urban social movements as a consequence of their too far-reaching institutionalization. 
